\title{
IMAGENS ORBITAIS DE ALTA RESOLUÇÃO APLICADAS NO MONITORAMENTO DO CRESCIMENTO URBANO E SUAS CONSEQÜÊNCIAS SOCIOAMBIENTAIS
}

\section{orbital images high resolution applied in monitoring of urban growth and its social and environmental consequences}

Mário Valério Filho ${ }^{1}$

Paulo Roberto Belisárioº

$a_{a} a_{a}$

\begin{abstract}
Resumo
A avaliação dos impactos do crescimento urbano sobre a capacidade geoambiental de uma bacia hidrográfica, requer uma análise da dinâmica do uso e ocupação do solo. Neste contexto, o presente trabalho apresenta uma abordagem metodológica, apoiada pelas geotecnologias, através da análise e interpretação das imagens orbitais de alta resolução para mapear os perímetros urbanos e poder relacioná-los com os eventos de inundações e processos de degradação ambiental na sub-bacia hidrográfica do Córrego Pararangaba localizada no setor leste do município de São José dos Campos - SP no período de 1997 a 2008. Os resultados obtidos no presente trabalho demonstram que o aumento dos perímetros urbanos no período, concorreram para a intensificação das inundações, dos processos de erosão e assoreamento dos sistemas de drenagem.
\end{abstract}

Palavras-chave: Crescimento Urbano, Imagens de Alta Resolução, Bacia Hidrográfica, Inundações, Processos de Erosão.

\begin{abstract}
This study presents a methodological approach, based on geo-technologies, for the analysis and interpretation of high resolution satellite images, to map urban perimeters, and to relate them with the environmental degradation processes occurring at the Pararangaba river, at the eastern periphery from São José dos Campos, in the timeframe 1997 to 2008 . The results obtained in this study demonstrate that the increase of the urban perimeter improved inundation and erosion processes as well as silting within the drainage systems.
\end{abstract}

Key words: Urban growth, High resolution images, Watershed, Floodplain, Inundation, Erosion Process.

\begin{abstract}
Resumen
Este estudio presenta un enfoque metodológico, basado en geo-tecnologías, para el análisis e interpretación de imágenes satelitales de alta resolución, para asignar los perímetros urbanos y relacionarlas con los procesos de degradación del medio ambiente ocurridos en el río Pararangaba, en la periferia oriental de São José dos Campos, en el período 1997 a 2008. Los resultados obtenidos en este estudio demuestran que el aumento del perímetro urbano mejorado inundación y procesos de erosión, así como sedimentación dentro de los sistemas de drenaje.

Palabras clave: Crecimiento urbano, Imágenes de alta resolución, Cuenca, Inundaciones, Procesos de erosión.
\end{abstract}

(1) Prof. Dr. da Universidade do Vale do Paraíba, Institudo de Pesquisa e Desenvolvimento. Av. Shishima Hifumi, 2911 Urbanova 12244-000 - São Jose dos Campos (SP), Brasil, Tel: (+55 12) 39471134 - ggo@ufba.br

(2) Mestre em Planejamento Urbano e Regional pela Universidade do Vale do Paraíba - Avenida Andrômeda, 753, CEP: 12230-000, São Jose dos Campos (SP), Brasil, Tel: (+55 12) 30339161 - guiomar@ufba.br

\section{aaAaa}

Revista da ANPEGE, v. 8, n. 9, p. 119 -135, jan./jul. 2012.

ISSN 1679-768 X @ 2003, Associação Nacional de Pesquisa e Pós-Graduação em Geografia. Todos os direitos reservados. 


\section{INTRODUÇÃO}

O processo de crescimento urbano desordenado a que foram submetidas a grande maioria das cidades de pequeno e médio portes localizadas na Região do Vale do Paraíba - SP, tem concorrido para uma ocupação de áreas nem sempre compatíveis com sua capacidade de suporte perante as legislações municipais.

Neste sentido, a expansão dos perímetros urbanos tem como resultante a impermeabilização do solo que por sua vez refletem na intensificação das inundações, alagamentos, e nos processos de erosão, assoreamento do leito dos sistemas de drenagem.

Segundo Freitas e Costa (2005), "na tentativa de ordenar a ocupação do solo urbano, e inibir a especulação imobiliária, têm sido elaboradas sucessivas leis urbanísticas municipais, bem como planos diretores, tão em voga no Brasil nas últimas décadas. Entretanto, esses instrumentos de planejamento têm se mostrado ineficazes, seguindo a reboque do crescimento urbano, vulneráveis à interesses corporativos".

Para Andrade et al. (2009), o estudo da expansão urbana requer o constante monitoramento e atualização dos dados referentes ao uso e ocupação do solo, a fim de inferir suas tendências. Face a esses requerimentos, Paes et al. (2003) afirmam que os aerolevantamentos para fins de monitoramento se tornaram inviáveis, pelo alto custo operacional, tornando-se inacessíveis para diversas prefeituras dos municípios brasileiros. Neste sentido, de acordo com Farina (2007), as novas técnicas de monitoramento da expansão das cidades que utilizam imagens orbitais de alta resolução, "empregam tecnologias mais adequadas para detectar em tempo quase real, a expansão urbana e as alterações ambientais decorrentes".

Para Paes et al. (2003) as imagens orbitais de alta resolução são adequadas ao "estudo temático dos setores intra-urbanos, especialmente com vistas à identificação e classificação de alvos intra-urbanos". De acordo com Farina et al. (2007), as imagens de uso livre do satélite Quick Bird 2, com resolução espacial de 0,6 metros lançado em 2001, reúne os atributos necessários a um sensor de reconhecimento de feições de detalhe.

Ainda segundo Farina et al. (2007), Campos et al. (2009), os Sistemas de Informações Geográficas (SIGs) se constituem em ferramentas de apoio fundamentais no planejamento urbano, pois permite a integração dos dados de diferentes fontes (sensores orbitais, GPS, mapas temáticos e analógicos, informação alfanumérica), bem como, criar um banco de dados gerado ao longo do tempo, possibilitando o acompanhamento e análise temporal da dinâmica de uso e ocupação dos espaços construídos

Neste sentido, o presente trabalho tem por objetivo mapear a evolução temporal do processo de urbanização e avaliar as taxas de crescimento na região da sub-bacia do Córrego Pararangaba São José dos Campos - SP, no período de 1997 a 2008 e relacioná-las com os eventos de inundação e os processos de degradação ambiental ocorridos na área de estudo.

\section{MATERIAIS E MÉTODOS}

A presente pesquisa foi conduzida na sub-bacia hidrográfica do Córrego Pararangaba, localizada entre os paralelos $23^{\circ} 10^{\prime} 27^{\prime}$ ' $\mathrm{S}$ e $23^{\circ} 15^{\prime} 17^{\prime}$ ' $\mathrm{S}$ e os meridianos $45^{\circ} 43^{\prime} 38^{\prime \prime} \mathrm{W}$ e $45^{\circ} 48^{\prime} 18^{\prime \prime}$ $\mathrm{W}$, abrangendo uma área total de $25,89 \mathrm{~km}^{2}$, que corresponde a $2,32 \%$ da área total do município de São José dos Campos-SP. Situa-se no extremo leste do município de São José dos Campos, próximo à divisa com o município de Caçapava-SP e apresenta dois afluentes principais: Córrego Pararangaba e Córrego do Bairrinho.

Segundo a Carta Geotécnica do Município CD-ROM "Cidade Viva 2007” (PREFEITURA MUNICIPAL DE SÃO JOSÉ DOS CAMPOS, 2007) a sub-bacia do Córrego Pararangaba, se faz representar pelas unidades geotécnicas denominadas de Planície Aluvionar, Colinas e Morrotes em sedimentos arenosos, Colinas e Morrotes em sedimentos argilosos (argila expansiva), Colinas e 
Morrotes em sedimentos argilosos (argila arenosa). Na região das cabeceiras de drenagem ocorrem morros com substrato de rochas graníticas e colinas e morros com embasamento cristalino com declividades acima de $30 \%$.

Segundo Bologna (2000, p.60), o Plano Diretor Preliminar de 1959, que precedeu o primeiro Plano Diretor do município de São José dos Campos, relata a forma caótica em que vinha se dando o desenvolvimento do município em função da ausência de critério de localização para instalação de novas indústrias, bem como, o estabelecimento dos loteamentos que expandiram para "zonas rurais periféricas ao núcleo urbanizado, transformando áreas produtivas em lotes pseudo-urbanos que dificilmente seriam habitados."

A região leste, a qual abrange a área de estudo, foi submetida a esse processo, pois de acordo com Oliveira e Costa (2001) a urbanização da área se deu de forma fragmentada, o que causou o aparecimento de vazios urbanos. Alguns loteamentos, impulsionados pela instalação da Petrobrás, em 1974, se estabeleceram sob forma desordenada nessa região.

\section{MATERIAIS}

No desenvolvimento da presente pesquisa foram utilizadas cartas topográficas na escala 1:10.000 elaboradas pela Secretaria de Planejamento do Estado de São Paulo, mapas temáticos disponíveis no CD-ROM Cidade Viva 2007 e 2008 obtidos junto a Prefeitura Municipal de São José dos Campos, mapa temático de classes de uso e ocupação do solo da bacia do Córrego Pararangaba para o ano 1997 na escala 1:10.000 segundo Valério Filho et al.( 2003). Foram também usadas Imagens do sensor Quick Bird da sub-bacia do Córrego Pararangaba para o ano de 2003 e 2008 em formato digital e analógico na escala 1:10.000 e o software SPRING (Sistema para Processamento de Informações Georeferenciadas), (CÂMARA et al., 1996).

\section{MÉTODOS}

A estruturação da base de dados foi realizada com o suporte do CD-ROM "Cidade Viva 2008" (PREFEITURA MUNICIPAL DE SÃO JOSÉ DOS CAMPOS, 2008) que contém material cartográfico e temático digital no formato SPRING (.spr) para os dados planimétricos e altimétricos do município de São José dos Campos - SP. Foi incorporado ao banco de dados o mapa temático digitalizado das Classes de Uso e Ocupação do Solo (1997 ) da área de estudo segundo Valério Filho et al. (2003), obtido a partir da análise e interpretação de fotografias aéreas coloridas na escala aproximada de 1:10.000, do sobrevôo realizado pelo Instituto Nacional de Pesquisas Espaciais -INPE em novembro de 1997.

A compartimentação da área de estudo da sub-bacia foi realizada por vetorização, em ambiente computacional considerando-se os divisores d'água e balizado pelos dados altimétricos do banco de dados do CD-ROM “Cidade Viva 2008” (PREFEITURA MUNICIPAL DE SÃO JOSÉ DOS CAMPOS, 2008).

Devido ao fato da imagem Quick Bird 2008 não abranger totalmente a área de estudo, foi montado o mosaico do restante da sub bacia do Córrego Pararangaba com a imagem Quick Bird ortorretificada de 2007 disponível no CD-ROM “Cidade Viva 2007” (PREFEITURA MUNICIPAL DE SÃO JOSÉ DOS CAMPOS, 2007).

Os mapas temáticos de uso e ocupação do solo da sub-bacia hidrográfica do Córrego Pararangaba para os anos 2003 e 2008, foram obtidos através da análise e interpretação das imagens orbitais (Quick BIRD 2) diretamente na tela do computador, entretanto a manipulação da imagem digital no ambiente computacional permitiu quando necessário, análises mais detalhadas através do atalho (Zoom) na barra de ferramentas do módulo Spring. As classes de uso ocupação do solo foram definidas através dos elementos de interpretação (tonalidade/cor, tamanho, forma, textura, padrão e dados colaterais) segundo padrões de uso e ocupação do solo, Valério Filho et al. (2003), conforme ilustrado pelas figuras a seguir. 

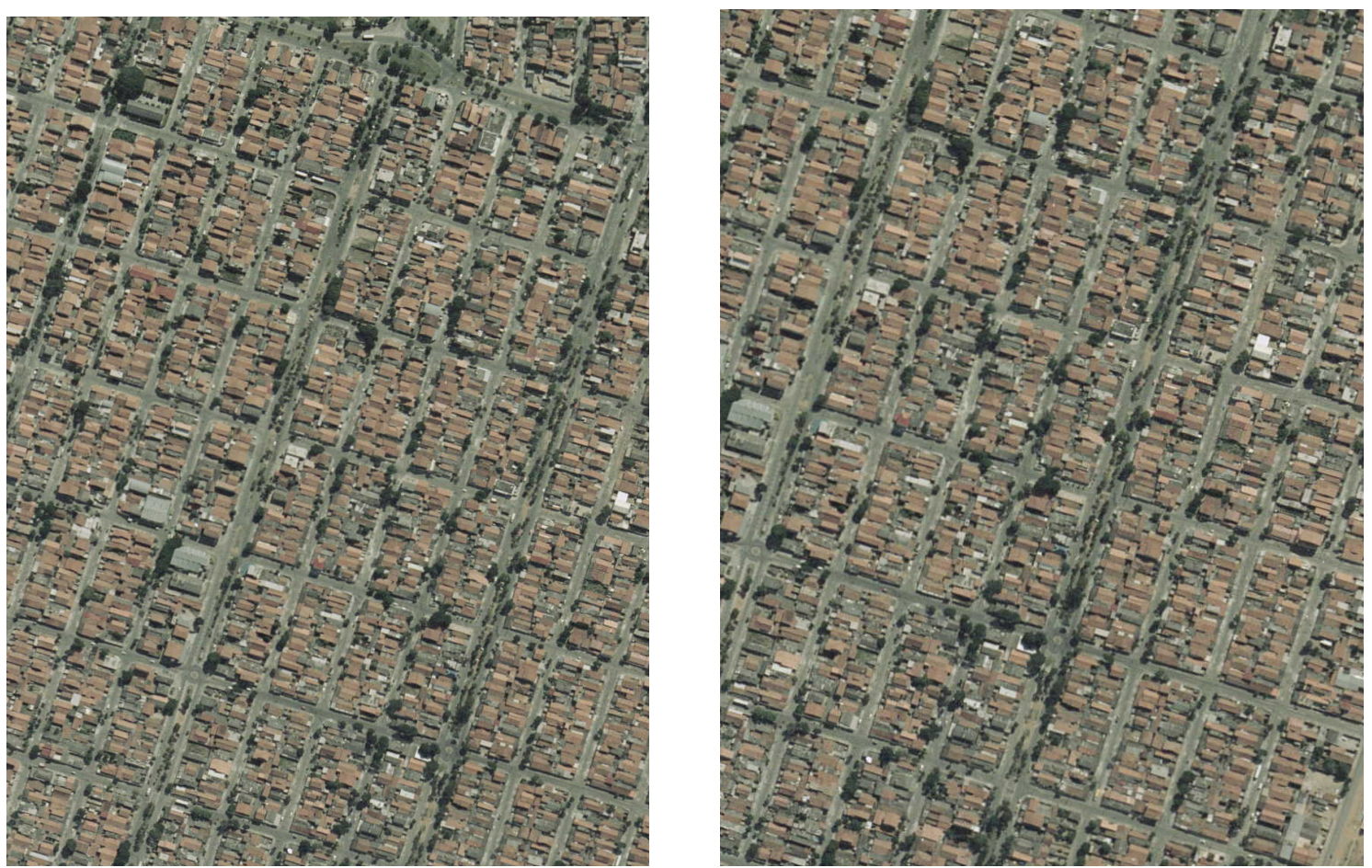

Figura 1 - Área Urbana Consolidada Alta Taxa de Ocupação. Corresponde às áreas de alta taxa de ocupação e com alta densidade de construções. Nessa classe há ausência de espaços livres. Há áreas ocupadas por construções em praticamente todo terreno. Vale ressaltar que foram incluídas áreas com vias pavimentadas e não pavimentadas.
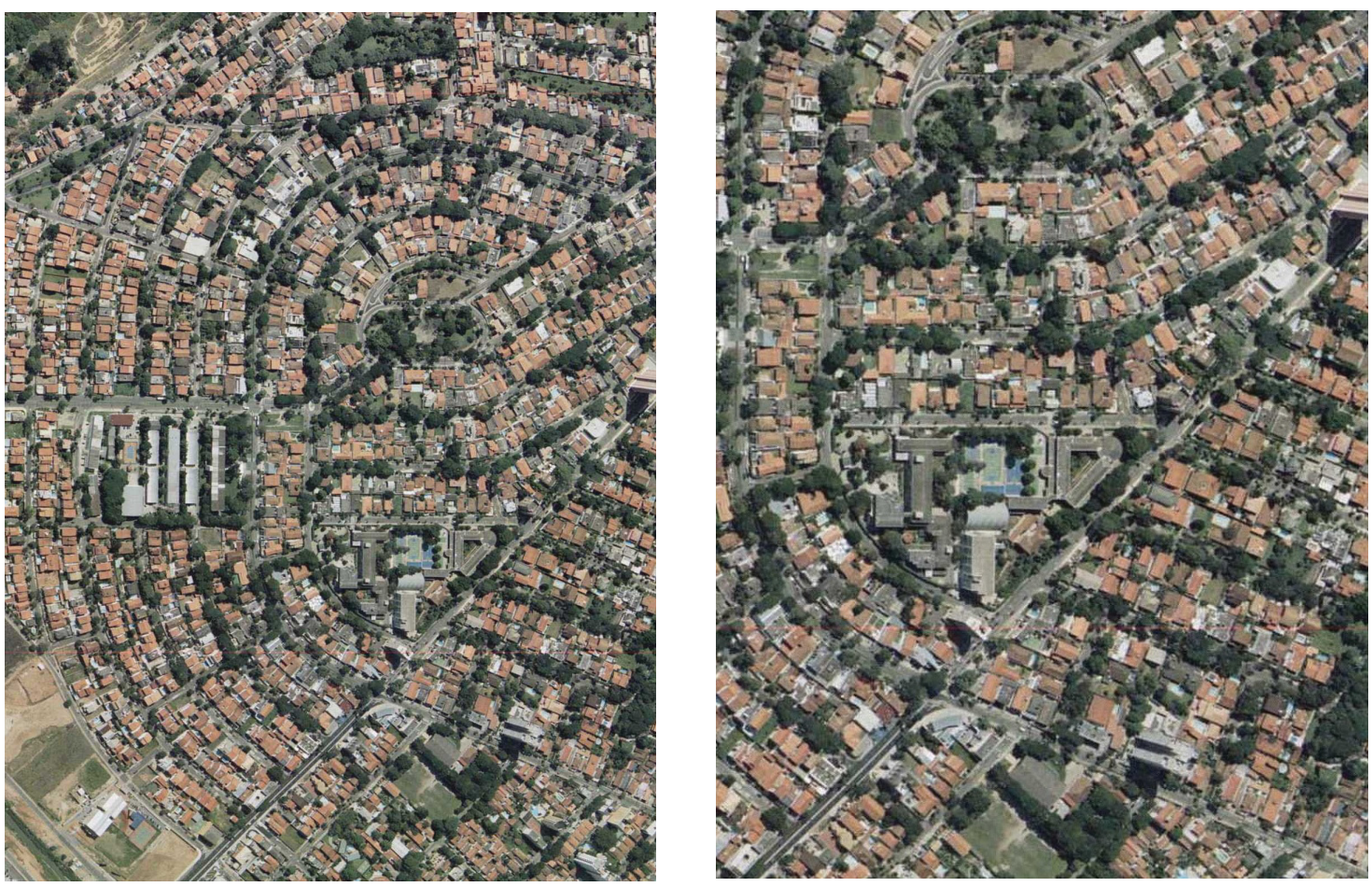

Figura 2 - Área Urbana Consolidada com Média Taxa de Ocupação. Corresponde às áreas com taxa de ocupação média, abrangendo as áreas residenciais de classe alta, áreas institucionais, áreas industriais de grande porte, parques urbanos e chácaras de recreação. Nessas classes ocorre a presença de espaços livres, como jardins gramados associados às indústrias e áreas institucionais, bem como de extensas áreas verdes urbanas como parques e praças urbanizadas. 

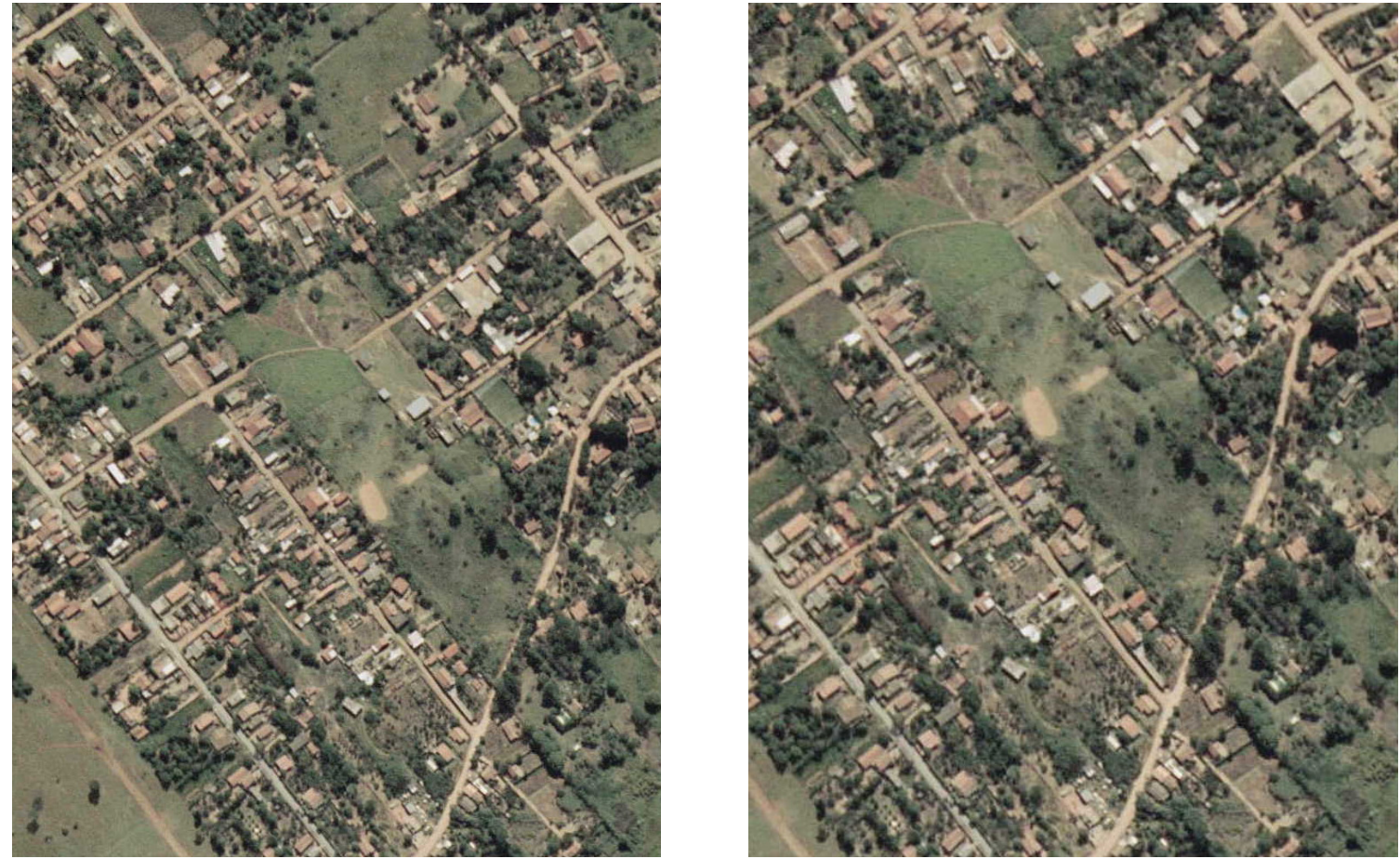

Figura 3 - Área Urbana Não Consolidada com Média Taxa de Ocupação. Corresponde às áreas com densidade média de habitações. Nessas áreas ocorre a presença de lotes ainda não ocupados por edificações. Nessa classe os terrenos vazios representam menor expressão de área comparativamente aos lotes ocupados e os acessos viários intraurbanos geralmente não são asfaltados.
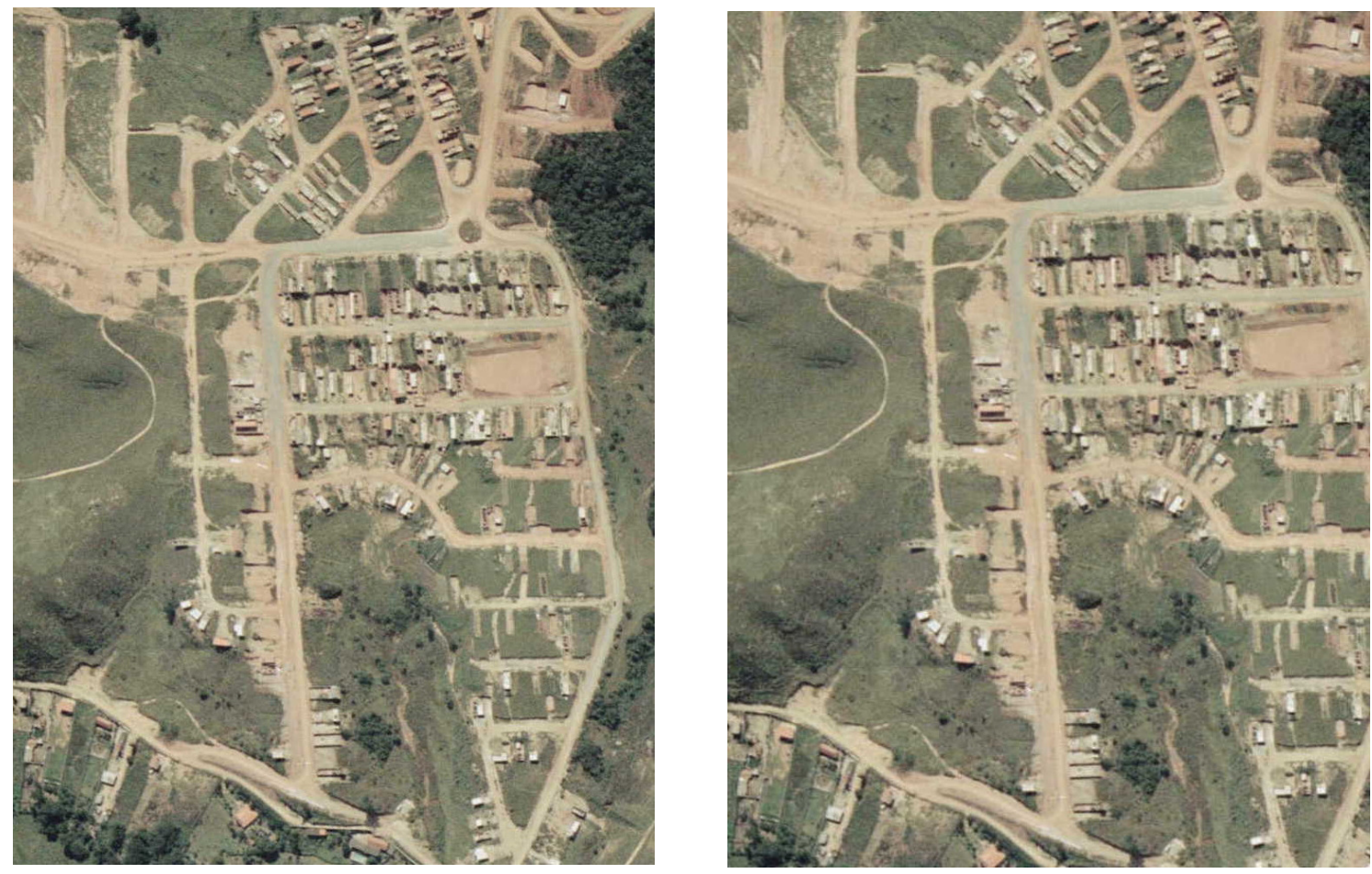

Figura 4 - Área Urbana Não Consolidada com Baixa Taxa de Ocupação. Corresponde às áreas ocupadas por edificações esparsas, loteamentos urbanos em processo inicial de ocupação. Nessas áreas a relação terrenos ocupados e terrenos vazios é baixa. Vale destacar que ambas as áreas não consolidadas são formadas predominantemente de loteamentos em processo de ocupação, com acessos viários sem asfalto. 

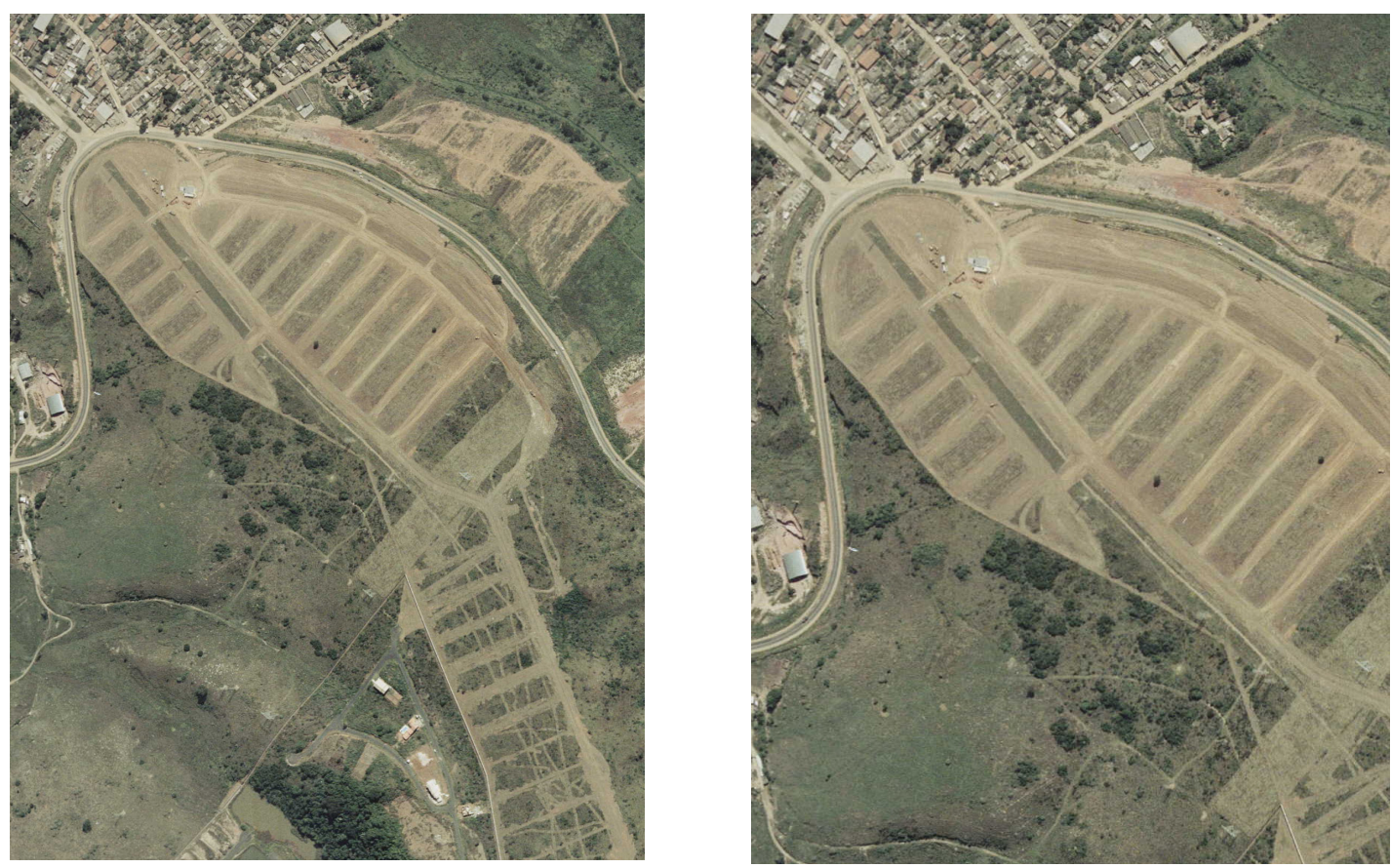

Figura 5 - Área em Implantação. Corresponde aos loteamentos com ausência de edificações, verificando-se apenas o traçado do sistema viário e áreas terraplanadas para implantação de loteamentos ou indústrias de médio a grande porte. Áreas basicamente não ocupadas por edificações, com abertura de vias e desbaste de quadras.
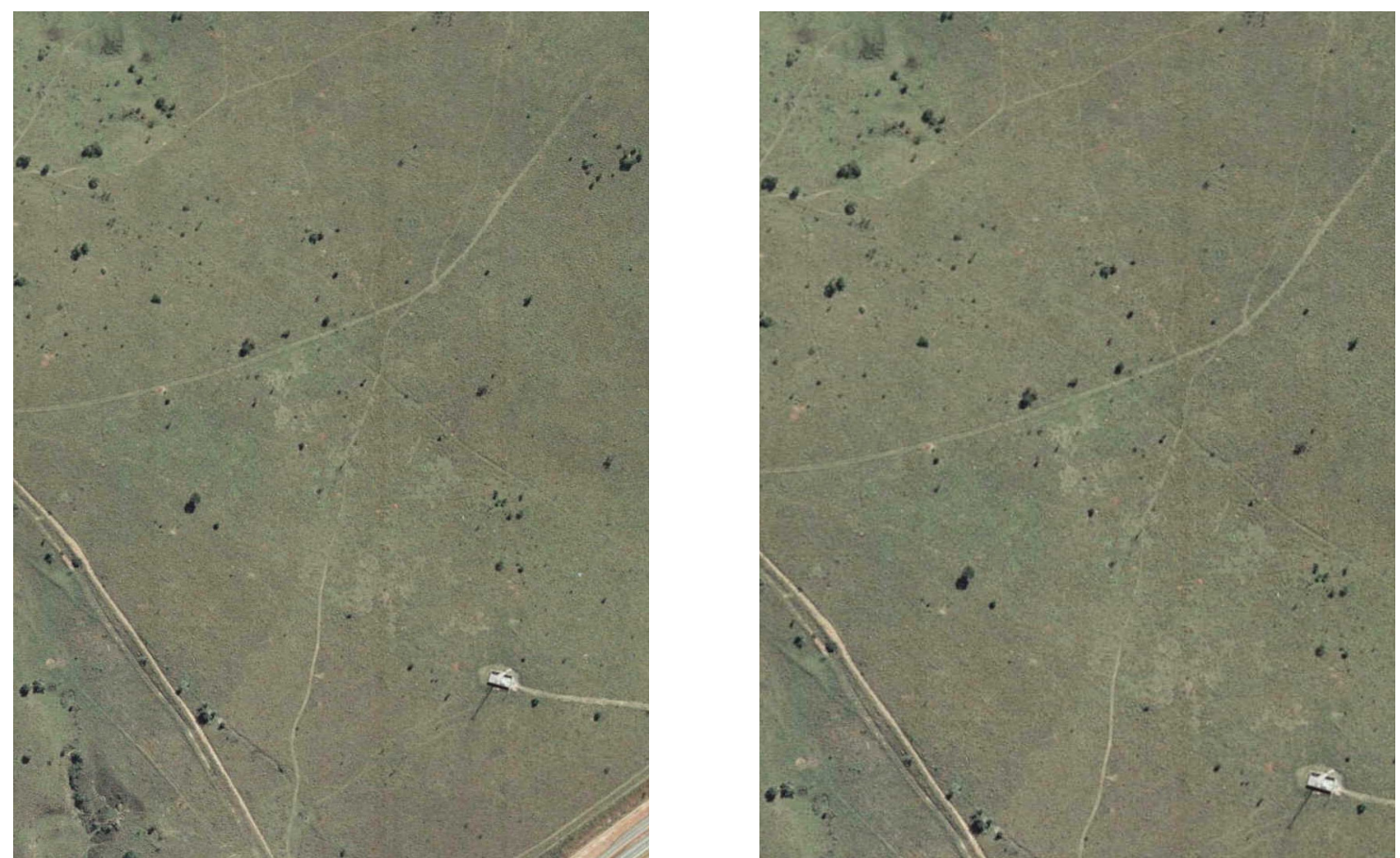

Figura 6 - Pastagem. Correspondem a áreas ocupadas por pastos naturais com cobertura dominante de gramíneas, melhorados ou plantados e por forrageiras de corte que tenham sido ou não utilizada para alimentação de animais de grande e médio porte. 

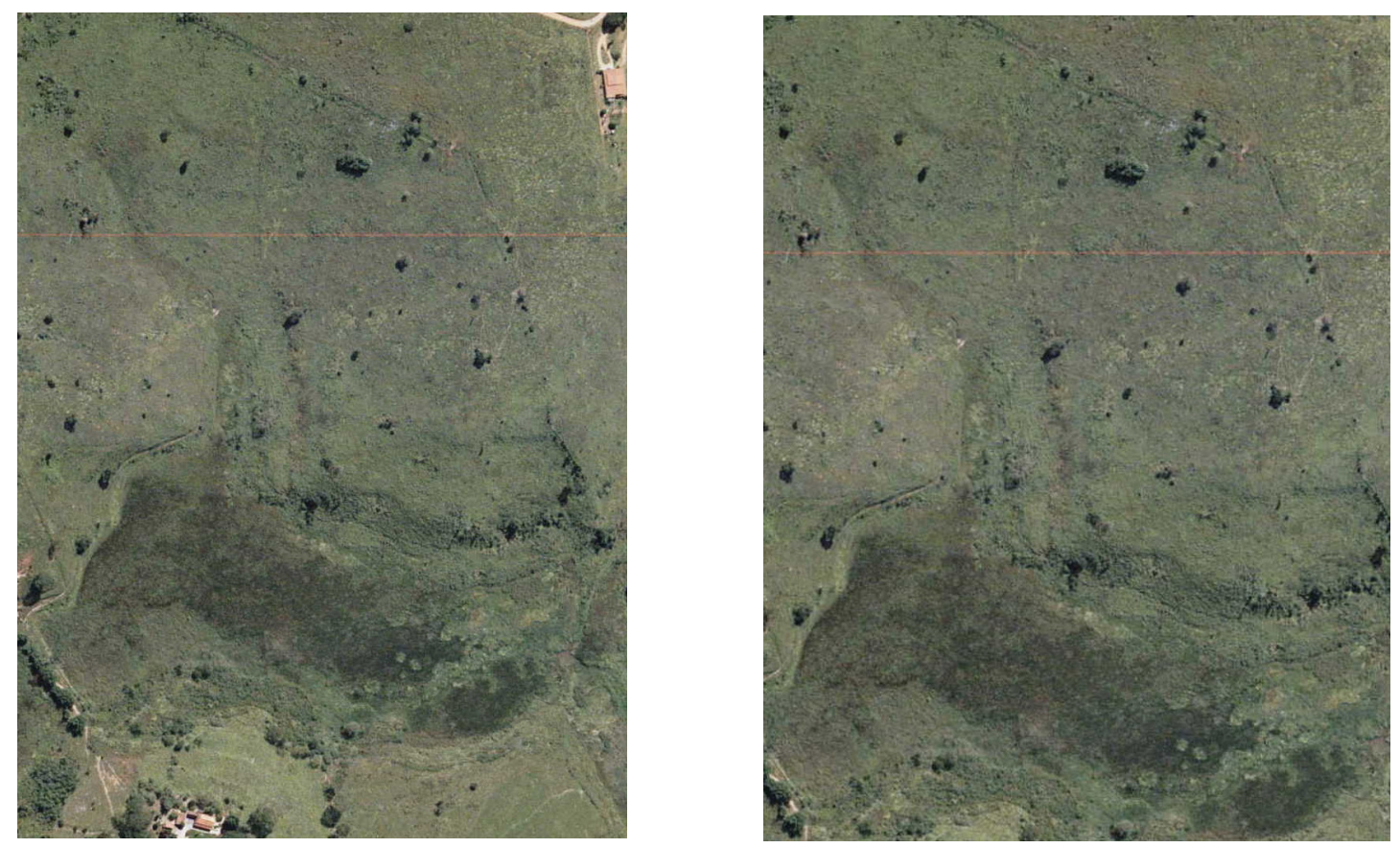

Figura 7 - Pasto sujo. As áreas de pasto sujo estão associadas às áreas de pastagem em que ocorre a presença de vegetação arbustiva. São englobados nesta classe os pastos não manejados sistematicamente.
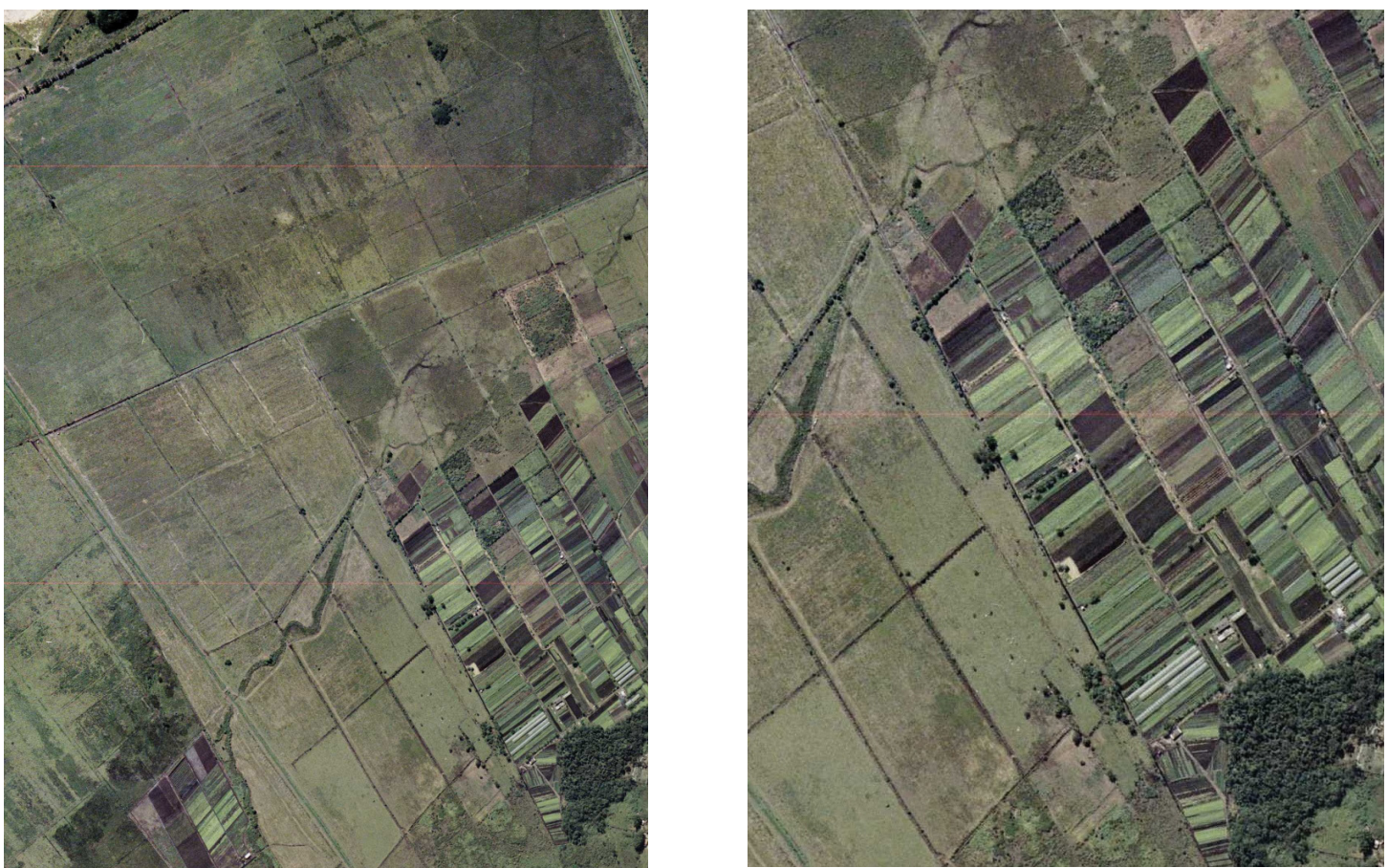

Figura 8 - Área Agrícola. Corresponde a áreas com predomínio de pequenas propriedades, mas que possuem certa representatividade em termos de área, levando-se em consideração a escala de trabalho. Encontram-se incluídas nestas áreas a atividade de horticultura, sobretudo com o cultivo de tomate, abobrinha e kiabo. 

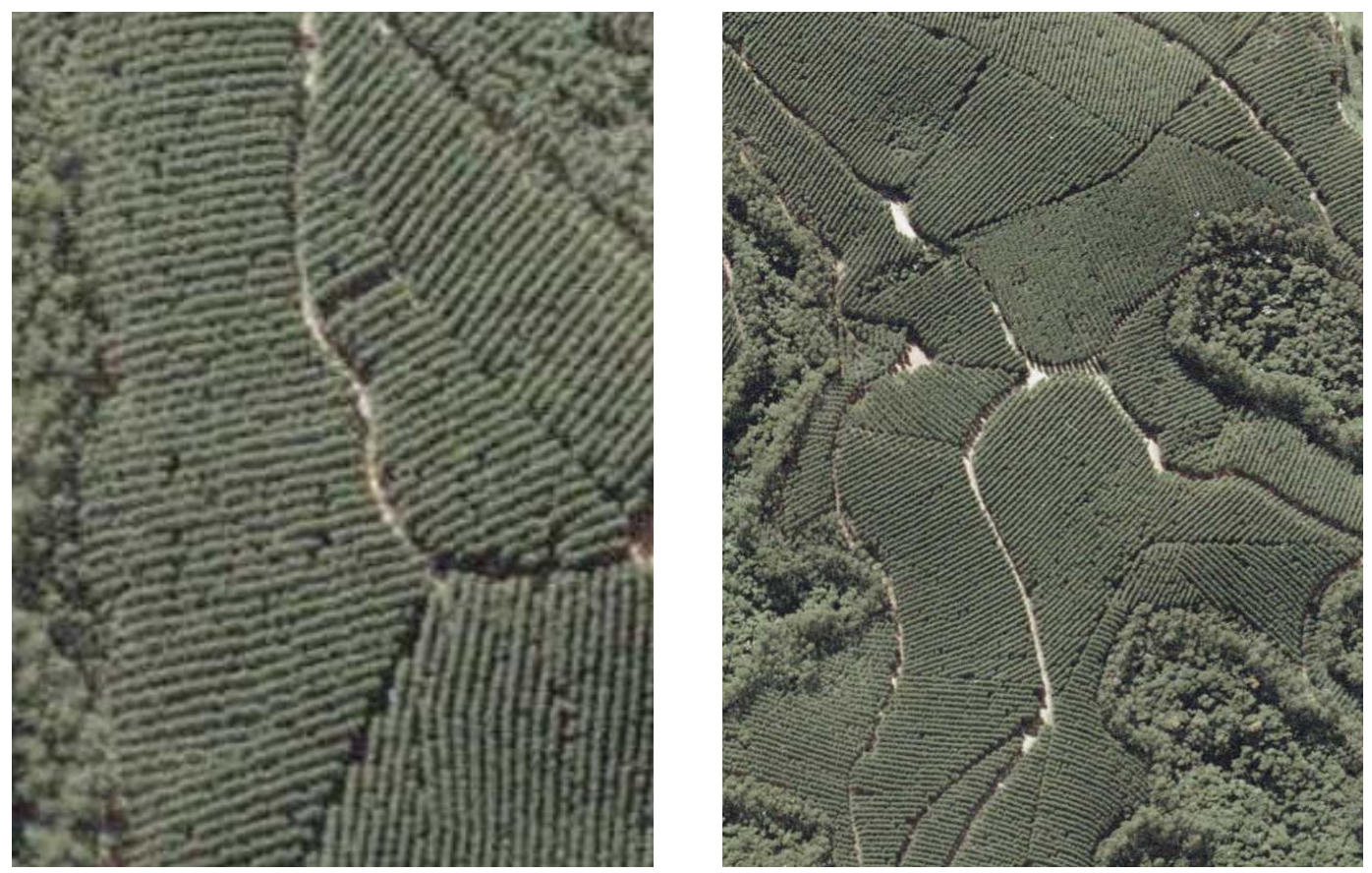

Figura 9 - Reflorestamento. São consideradas áreas de reflorestamento aquelas que apresentam árvores produtoras de madeira e outros produtos florestais, correspondendo às classes de reflorestamento de Pinus e Eucalipto em diferentes estágios de crescimento.
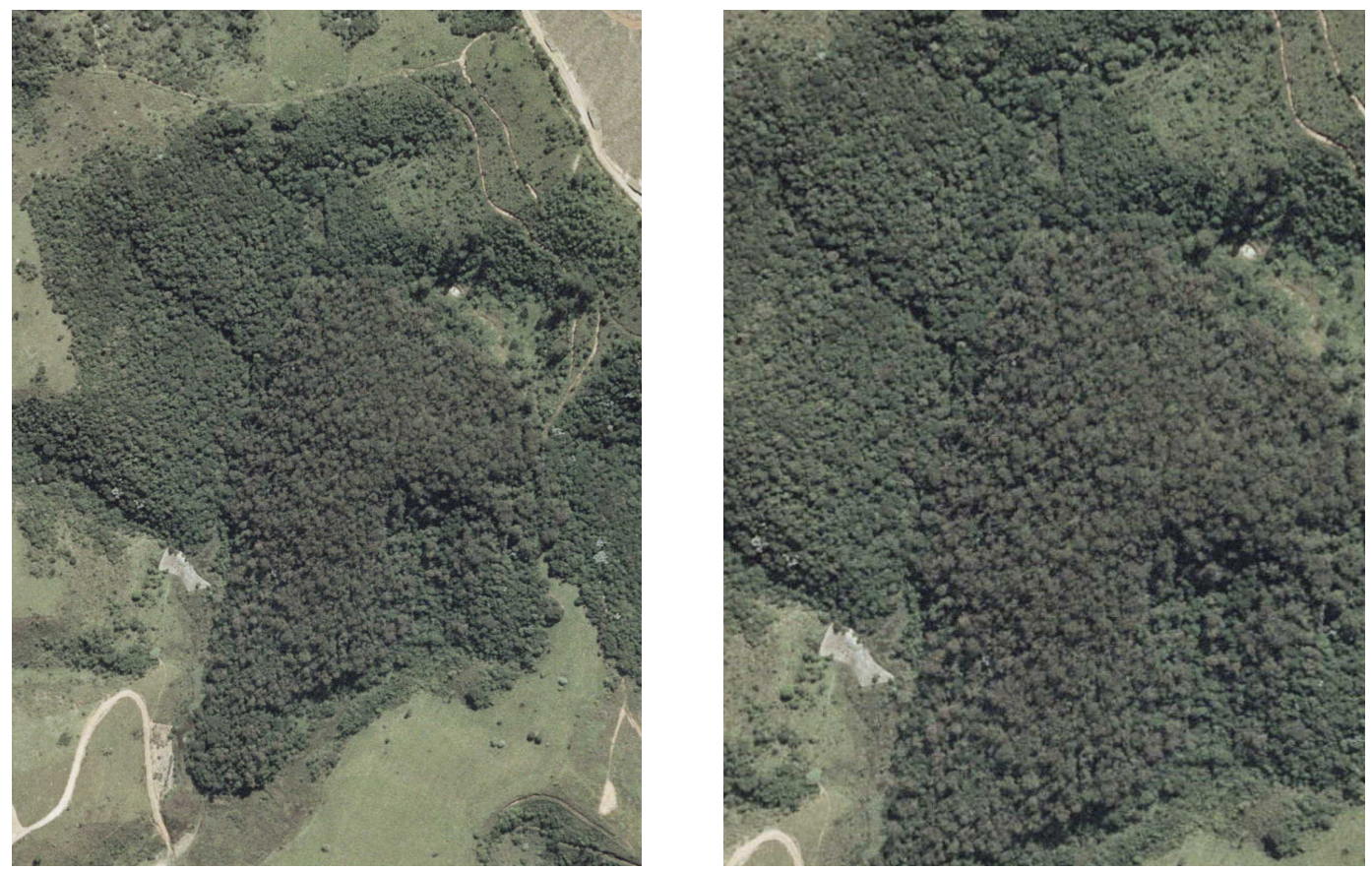

Figura 10 - Mata / Capoeira. Correspondem à vegetação arbórea nativa de porte alto e fechada, com grande variedade de espécies, em geral de forma aleatória.

Posteriormente, as classes de uso e ocupação do solo foram espacializadas para toda a área de estudo e quantificadas. Os resultados obtidos, possibilitaram identificar os setores da bacia que apresentam diferentes níveis de adensamento urbano que por sua vez concorrem para sobrecarregar os sistemas de drenagem. 
As informações referentes à evolução temporal dos eventos de inundações, foram obtidas junto à Defesa Civil do município para a área de estudo no período de 1997 a 2008.

Os dados pluviométricos relativos ao período em análise foram disponibilizados pelo Comando da Aeronáutica / Diretoria de Eletrônica e Proteção ao Vôo / Divisão de Meteorologia Aeronáutica do Centro Tecnológico de Aeronáutica. Esses dados foram relacionados com as ocorrências das inundações fornecidos pela Defesa Civil.

\section{RESULTADOS E DISCUSSÃO}

A Figura 11 apresenta os mapas de uso e ocupação do solo de 1997 (Valério Filho et. al. 2003) e relativos a 2003, e 2008 obtidos através da análise e interpretação das imagens do sensor Quick Bird. A análise dos mapas permite visualizar o crescimento urbano no período, onde se verifica que o crescimento dos perímetros urbanos passaram a ocupar áreas antes ocupadas pelas classes denominadas pastagem e o adensamento dos perímetros urbanos implantados anteriormente, bem como, a expansão da silvicultura de eucalípto em período mais recente. As áreas, onde se verifica o processo de ocupação mais intenso estão localizadas entre duas importantes rodovias: a SP- 70, Governador Carvalho Pinto, à montante, e a BR-116, Presidente Dutra, à jusante.

Segundo Langenbuch (1971), Goya (1998), e Marcondes (1999), historicamente o sistema viário e de transportes são importantes elementos indutores do processo de urbanização. Neste sentido, pode-se constatar que as regiões que antecedem a confluência dos córregos e à jusante desta se apresentam como as áreas mais adensadas segundo suas classes de ocupação urbana, conforme apresentado na Figura 11 na sequência do período analisado.

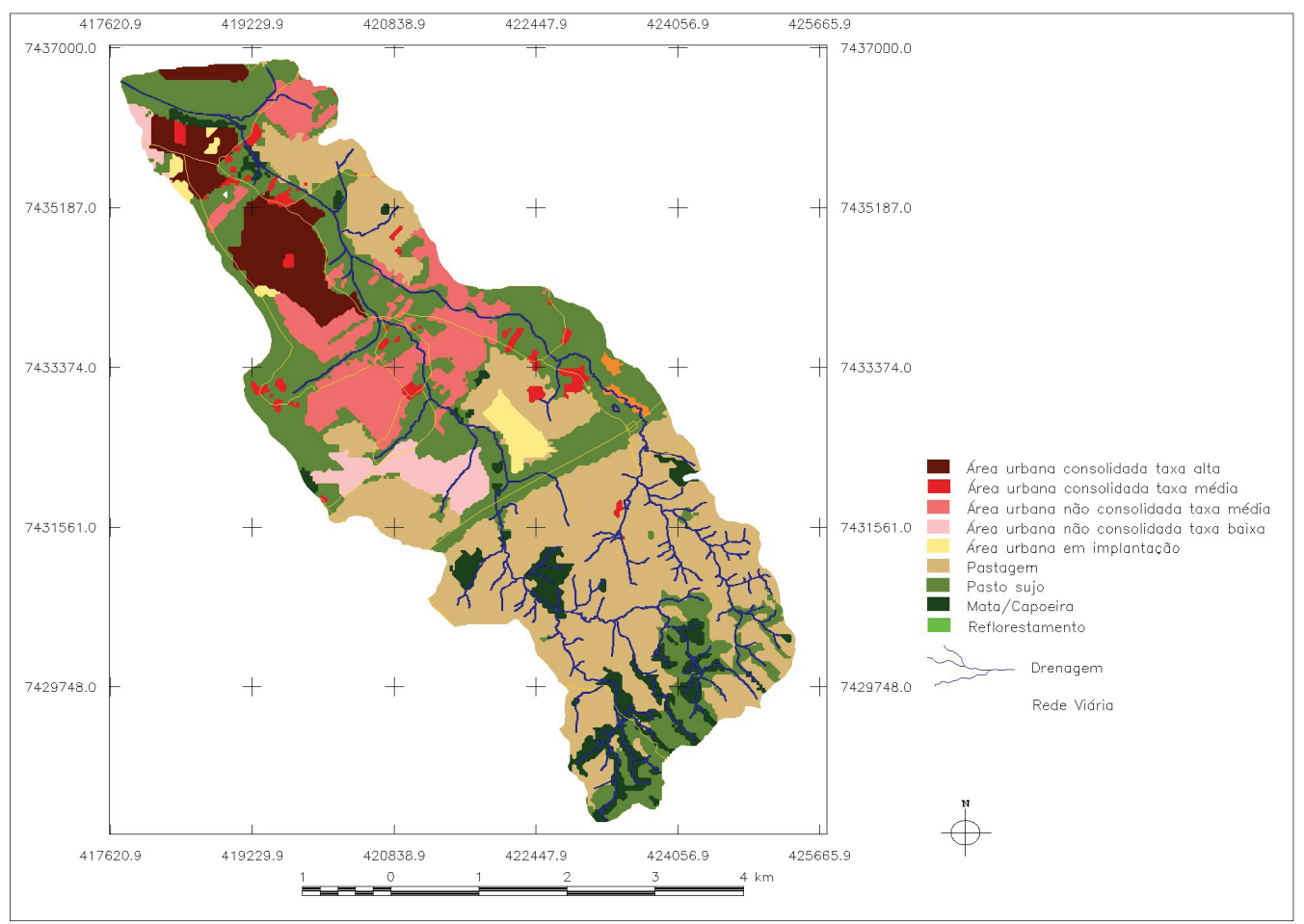

Figura 11- Mapeamento das Classes de Uso e Ocupação do Solo na Sub-bacia do Córrego Pararangaba (a) ano 1997 


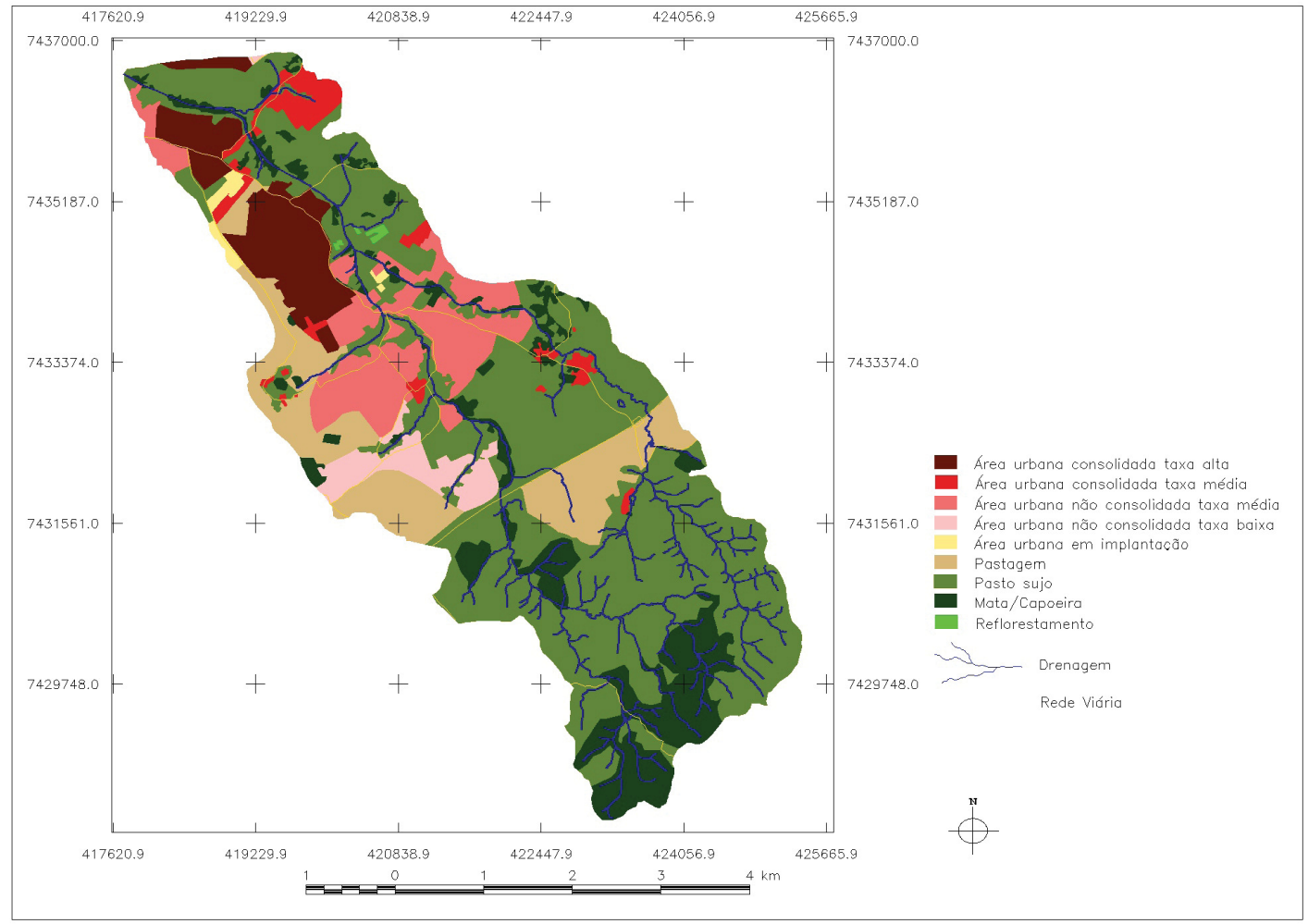

Figura 11- Mapeamento das Classes de Uso e Ocupação do Solo na Sub-bacia do Córrego Pararangaba (b) 2003

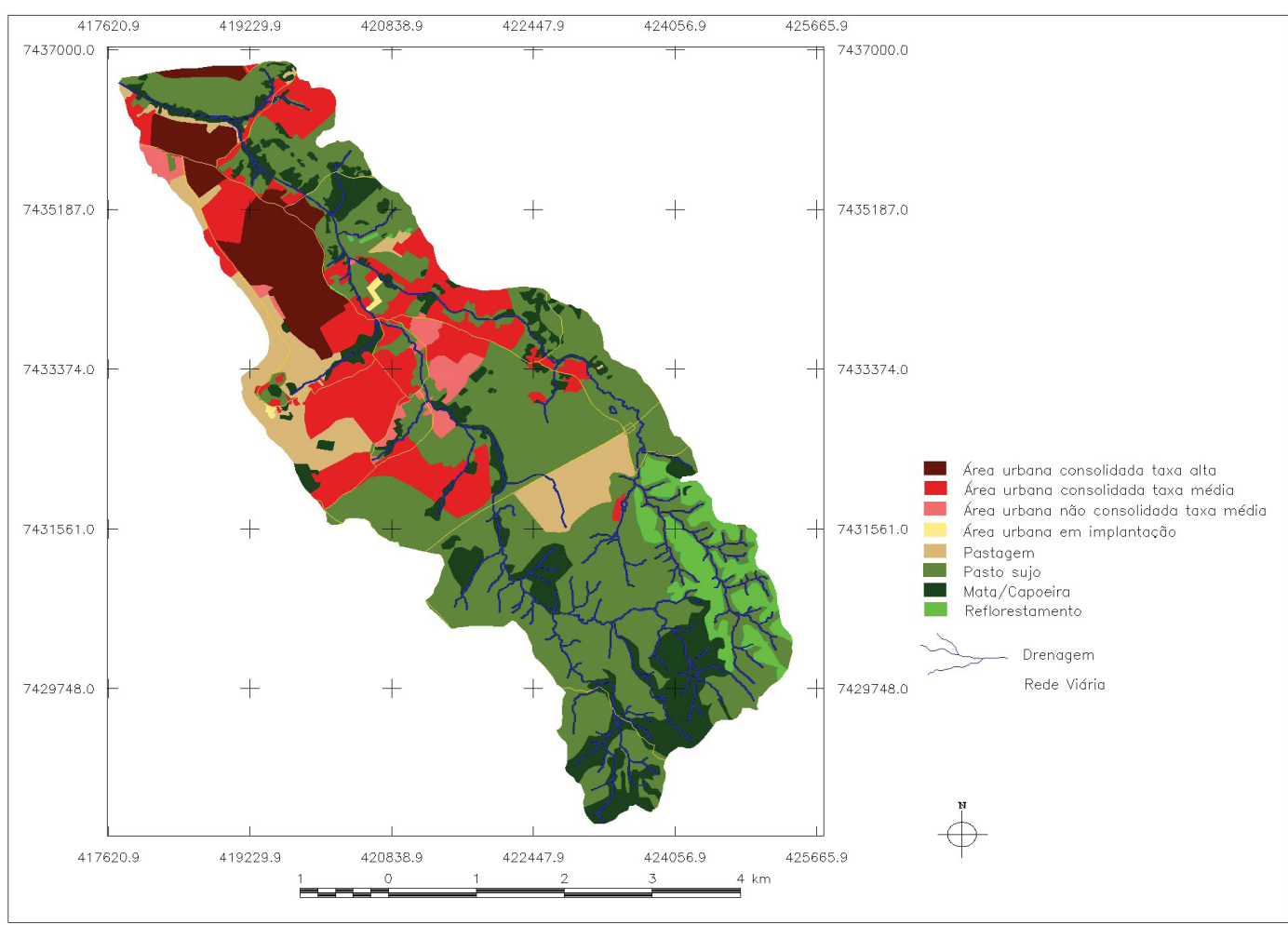

Figura 11- Mapeamento das Classes de Uso e Ocupação do Solo na Sub-bacia do Córrego Pararangaba (c) 2008 
A Tabela 1 quantifica a evolução dos diferentes usos no período analisado.

Tabela 1 - Áreas ocupadas pelas diferentes classes de uso e ocupação do solo para os anos 1997, 2003 e 2008 na sub- bacia hidrográfica do Córrego Pararangaba.

\begin{tabular}{|l|c|r|r|r|r|r|}
\hline \multicolumn{7}{|c|}{ Sub Bacia do Córrego Pararangaba (Área Total 25,89 $\mathrm{Km}^{2}$ ) } \\
\hline Classes de Uso e Ocupação do Solo & $1997\left(\mathrm{Km}^{2}\right)$ & $1997(\%)$ & $2003\left(\mathrm{Km}^{2}\right)$ & $2003(\%)$ & $2008\left(\mathrm{Km}^{2}\right)$ & $2008(\%)$ \\
\hline Área Urbana Consolidada Alta & 1,76 & 6,79 & 1,83 & 7,07 & 1,97 & 7,60 \\
\hline Área Urbana Consolidada Média & 0,45 & 1,73 & 1,48 & 5,72 & 4,73 & 18,27 \\
\hline Área Urbana Não Consolidada Média & 2,73 & 10,54 & 2,82 & 10,89 & 0,77 & 2,97 \\
\hline Área Urbana Não Consolidada Baixa & 0,85 & 3,28 & 1,35 & 5,21 & 0,00 & 0,00 \\
\hline Áreas em Implantação & 0,45 & 1,73 & 0,17 & 0,66 & 0,05 & 0,19 \\
\hline Área Agrícola & 0,09 & 0,34 & 0,00 & 0,00 & 0,00 & 0,00 \\
\hline Mata Capoeira & 1,59 & 6,14 & 3,21 & 12,40 & 3,42 & 13,20 \\
\hline Pastagem & 9,97 & 38,50 & 4,36 & 16,84 & 3,55 & 13,71 \\
\hline Pasto Sujo & 8,00 & 30,89 & 10,64 & 41,10 & 10,07 & 38,89 \\
\hline Reflorestamento & 0,00 & 0,00 & 0,03 & 0,12 & 1,33 & 5,14 \\
\hline Total & 25,89 & 100,00 & 25,89 & 100,00 & 25,89 & 100,00 \\
\hline
\end{tabular}

Pelos resultados apresentados, pode-se inferir que as taxas de crescimento urbano constatadas no período, tem como resultante imediata o aumento da impermeabilização do solo. Assim sendo, o crescimento urbano ao aumentar a impermeabilização do solo concorre para intensificar o escoamento superficial das águas pluviais, o que compromete a capacidade de suporte de drenagem ao longo de uma bacia hidrográfica, aumentando a probabilidade de eventos de inundações à jusante da bacia. Esta premissa pode ser constatada pela Figura 12 ao analisar o crescimento urbano para o ano de 2003 e o conseqüente aumento das inundações.

O registro do número de eventos de inundação, disponibilizados pelo setor de Defesa Civil da PMSJC, conforme Figura 12, para os bairros localizados na bacia hidrográfica do Córrego Pararangaba, mostram que no período de análise, com exceção do ano 2006, no qual a inundação ocorreu no mês de fevereiro no bairro Bom Retiro, o restante das ocorrências foram registradas no mês de janeiro, no bairro Jardim Nova Detroit.

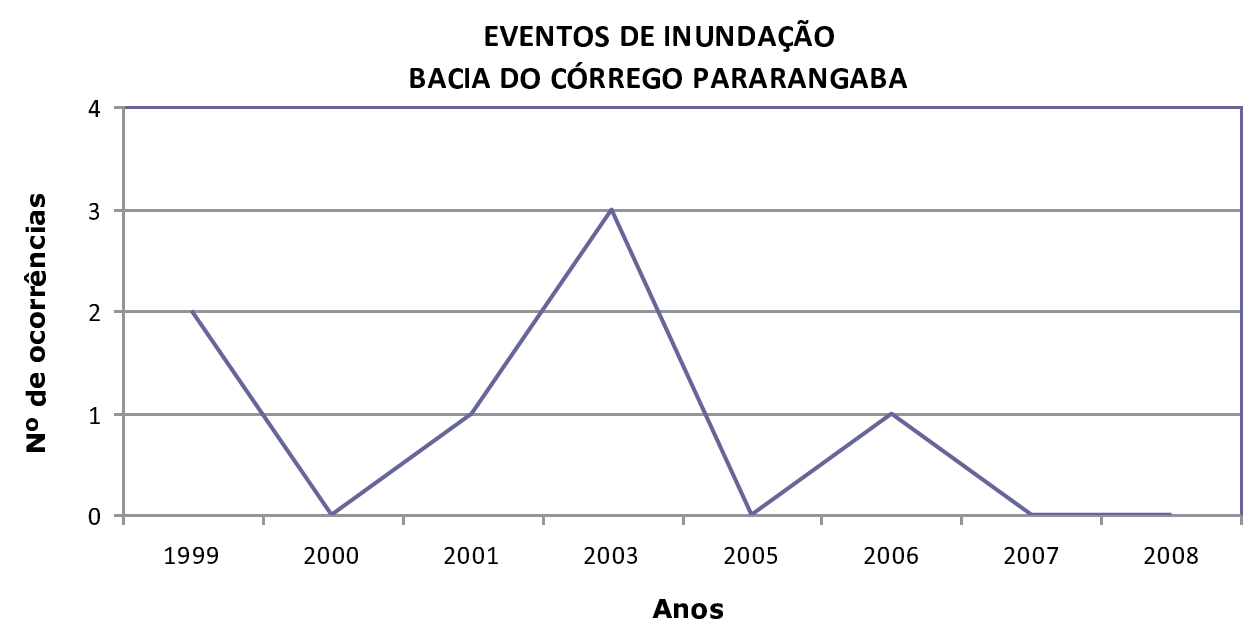

Figura 12 - Evolução temporal dos eventos de inundação no período 1999 a 2008. Fonte: PMSJC - Defesa Civil (2009). 
Esse resultado corrobora a afirmação de Oliveira (2003), pois o bairro localiza-se à jusante da confluência dos córregos do Bairrinho e Pararangaba, onde a capacidade da calha do Córrego Pararangaba é insuficiente para as vazões desses afluentes.

A análise do número de ocorrências indica que o ano 2003 apresentou o maior número, especificamente nos dias 21, 24 e 29 do mês de janeiro, no bairro Jardim Nova Detroit.

Com base nos índices de precipitação diária disponibilizados pela Divisão de Meteorologia Aeronáutica do Centro Tecnológico de Aeronáutica e os eventos de inundação (Figura 12), verifica-se que embora o total de precipitação acumulada de 311,1 mm no mês de janeiro de 2003 (Figura 13), tenha superado a média histórica de $210,7 \mathrm{~mm}$ para esse mês, conforme Figura 14, os eventos ocorreram tanto nos dias de maior precipitação, 21 de janeiro $(59,4 \mathrm{~mm})$, cerca de $19,09 \%$ do acumulado no mês, quanto para os dias de menor precipitação, 29 de janeiro (19 mm), referente a $6,10 \%$ do acumulado para o mês de janeiro de 2003 .

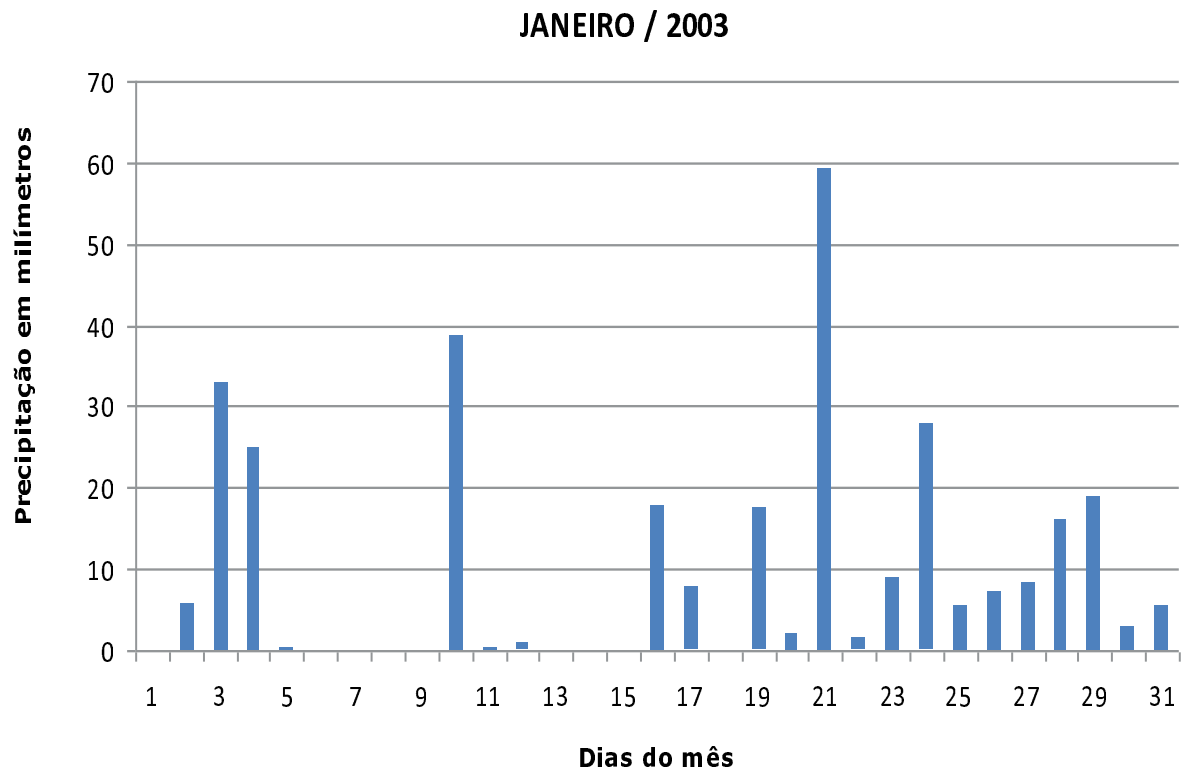

Figura 13 - Índices pluviométricos para o mês de janeiro de 2003.

Divisão de Meteorologia Aeronáutica do Centro Tecnológico de Aeronáutica (2003).

Estas ocorrências estão em parte relacionadas com o crescimento urbano que vem ocorrendo ao longo da bacia, conforme demonstrado pela Figura 11 e Tabela 1 para o período de análise.

Considerando-se que na área de estudo houve um crescimento urbano, pode-se inferir que embora o Bairro Jardim Nova Detroit esteja localizado fora da área de estudo, mas à jusante da sub-bacia do Córrego Pararangaba, os eventos de inundação no local são resultantes do aumento da impermeabilização do solo que vem ocorrendo à montante da sub-bacia do Córrego Pararangaba, principalmente nas áreas com loteamentos clandestinos. 


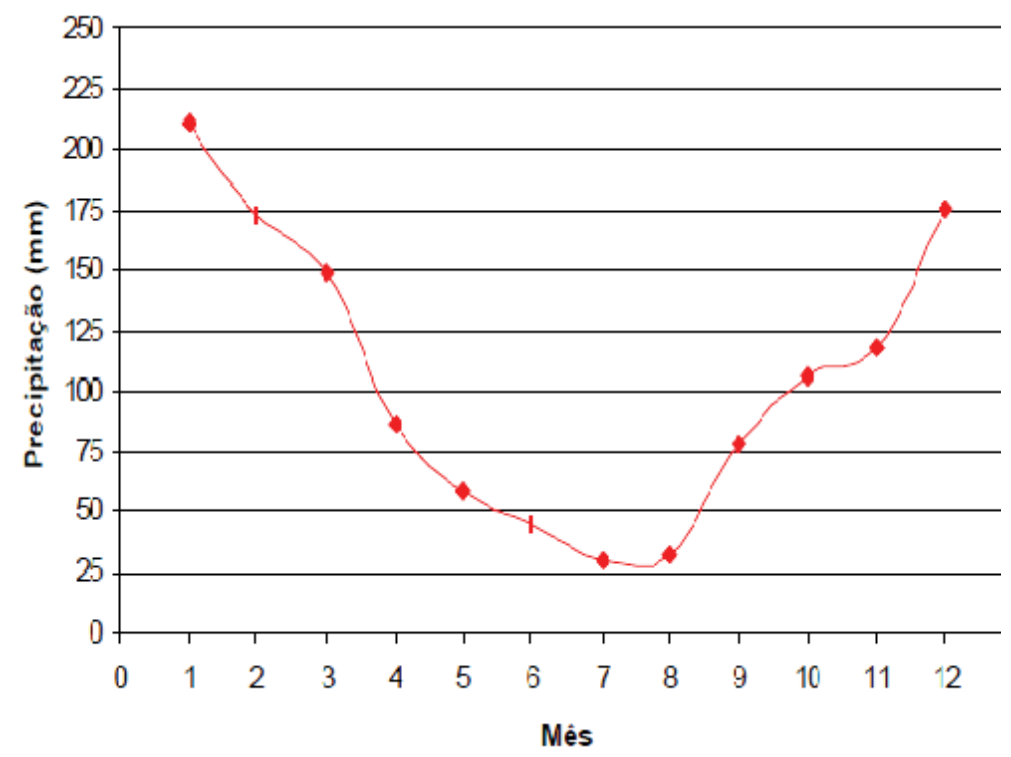

Figura 14 - Precipitação média mensal para o período de 1974 a 1998 Fonte: Scofield et al. (2000)

Esta situação pode ser ainda respaldada por informações obtidas junto ao banco de dados de um jornal da imprensa local (Jornal Valeparaibano, 2003), o qual relata que as ocorrências de inundações no dia 21 de janeiro 2003 ocorreram no Bairro Nova Detroit quanto no Bairro Bom Retiro, sendo que este último está inserido na área de estudo conforme ilustra a Figura 15. Segundo o Jornal O Vale de (2010), em janeiro de 2008 o Bairro Nova Detroit foi afetado novamente por inundações atingindo mais de 50 residências.

Diferente dos registros da Defesa Civil, segundo o Jornal Valeparaibano (23 de janeiro) informou que as ocorrências de inundações no dia 21 de janeiro 2003 se deram tanto no Bairro Nova Detroit quanto no Bairro Bom Retiro, este último localizado na área de estudo conforme ilustra a Figura 15. Em janeiro de 2008 as inundações ocorreram no Bairro Nova Detroit, afetando mais de 50 residências (Jornal O Vale, 2010). 


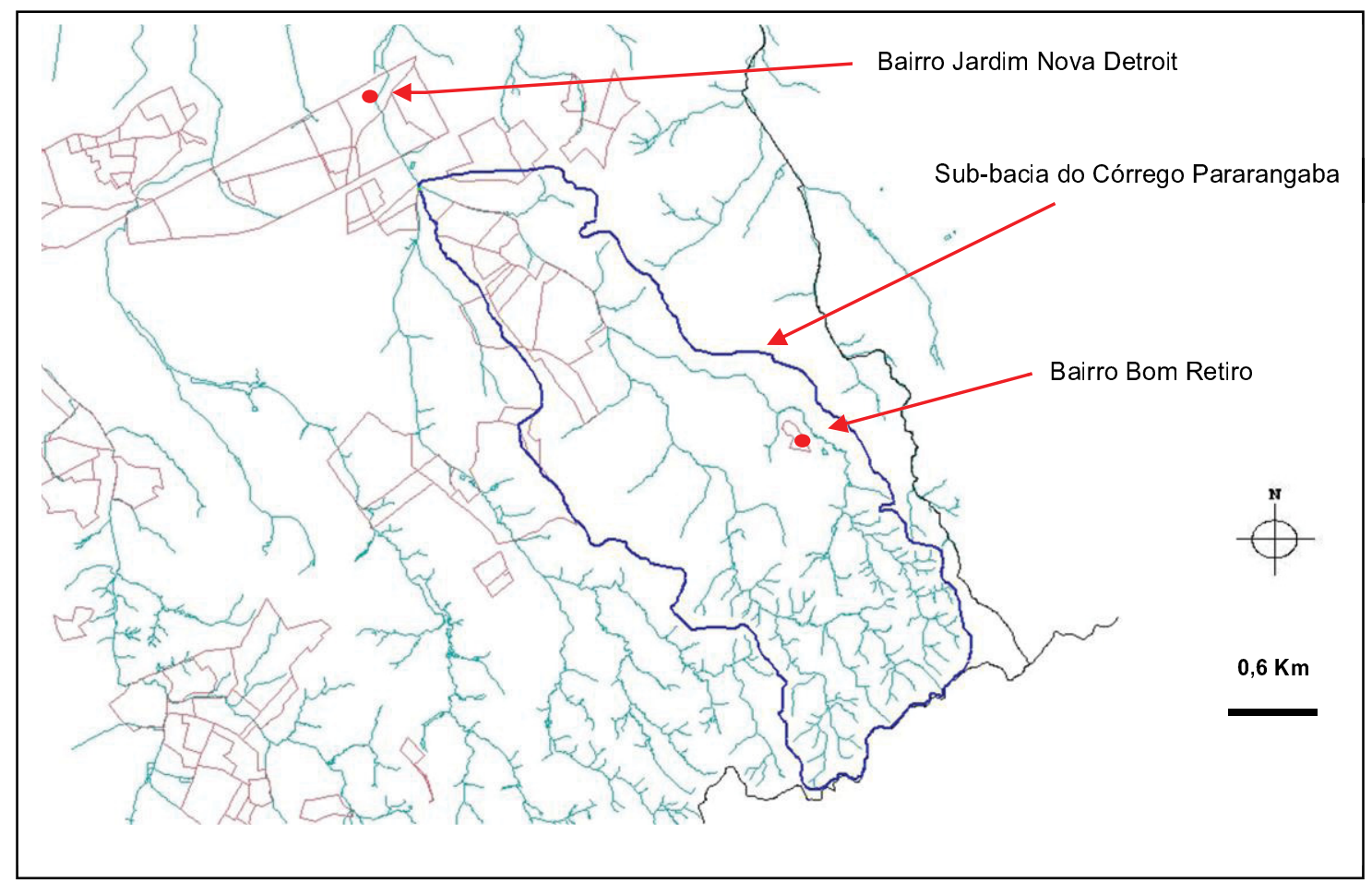

Figura 15 - Localização dos bairros onde ocorreram as inundações em 2003. Fonte: Prefeitura Municipal de São José dos Campos (2010)

O fato de ter como fonte oficial o registro de eventos de inundações da Defesa Civil do município, limitou a possibilidade de uma análise mais completa, pois segundo Perrella (2002) "tais deficiências foram constatadas" ao consultar os registros e "verificar que alguns episódios significativos" de inundação não constavam nos registros da Defesa Civil da cidade de São José dos Campos.

Os perímetros urbanos na bacia hidrográfica do Córrego Pararangaba são em grande parte ocupados por habitações instaladas em áreas de infra estrutura incompleta quanto ao saneamento básico. Nestas condições a ausência de asfalto, redes pluviais e demais sistemas de circulação, concorre para uma ação direta dos processos de erosão pelo aumento do escoamento superficial por ocasião do período de chuvas, provocando assim a erosão das vias de acesso e assoreamento de córregos e rios receptores de águas pluviais provenientes desses locais conforme ilustrado pelas Figuras 16 e 17.

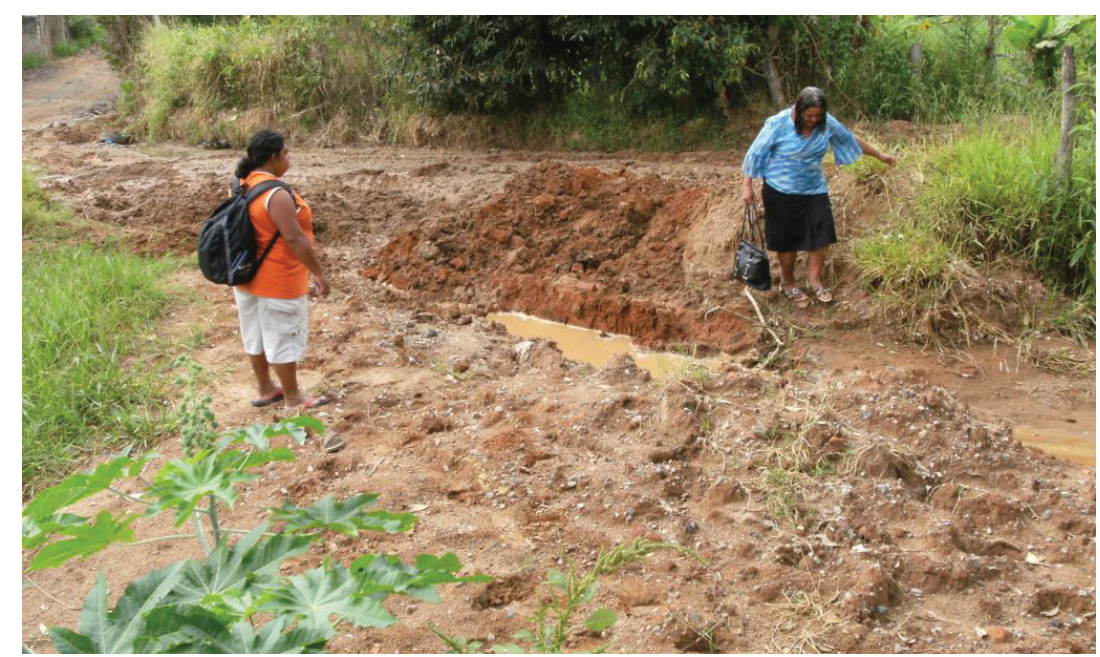

Figura 16 - Vias de acesso com erosão provocada pelo escoamento superficial das águas pluviais. 


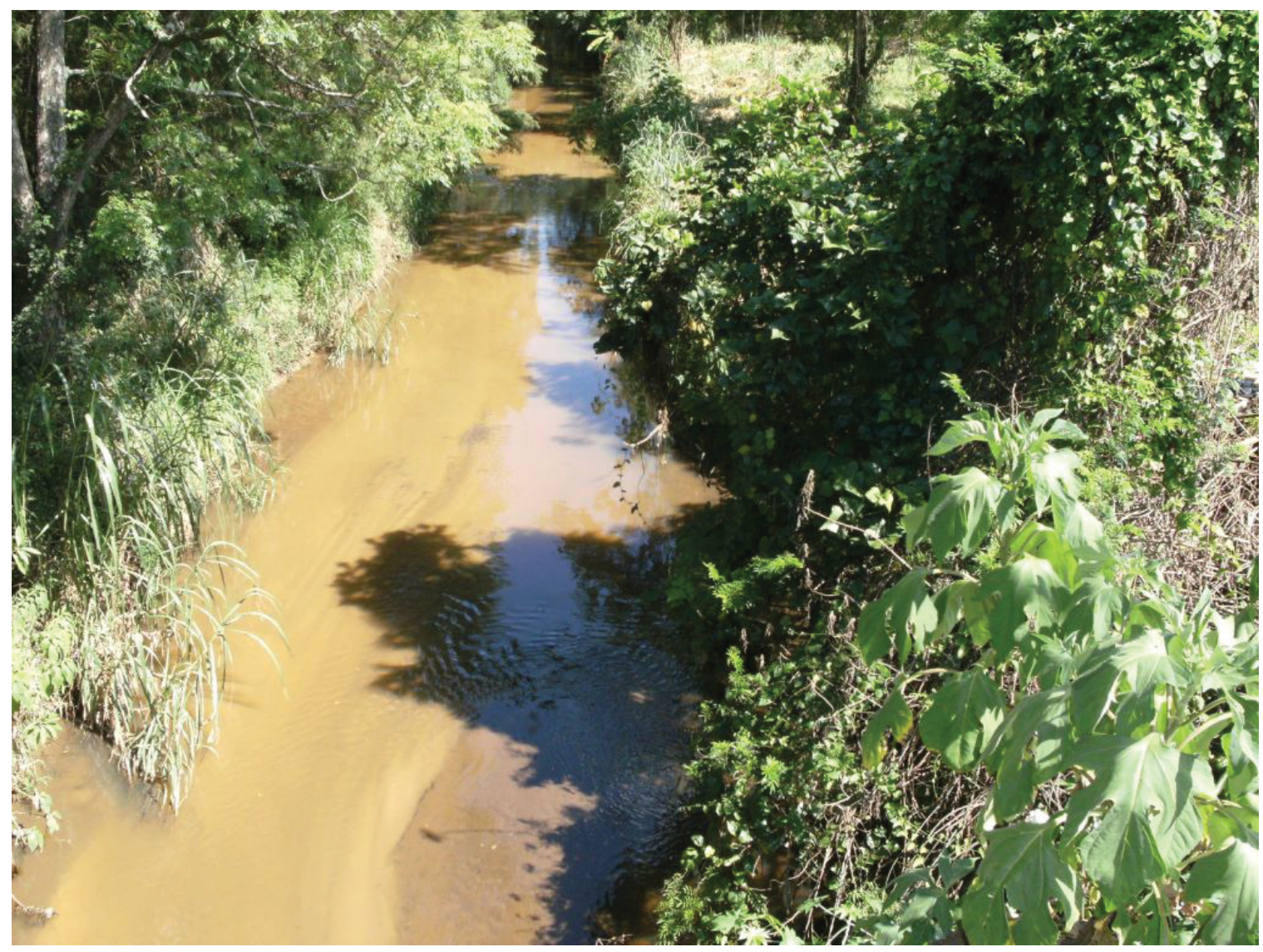

Figura 17 - Assoreamento no leito do Córrego Pararangaba no terço superior da sub-bacia.

Estes fatos confirmam o que é descrito em Tucci (2003, p.23), “com a modificação da cobertura da bacia pela retirada da sua proteção natural, o solo fica desprotegido e a erosão aumenta no período chuvoso aumentando também a produção de sedimentos", originários igualmente da movimentação de terra em áreas em construção, que são transportados pelo escoamento superficial provocando a remoção das camadas superficiais do solo através dos processos de erosão e causando assoreamento nos corpos d'água receptores.

\section{CONSIDERAÇÕES FINAIS}

A metodologia desenvolvida no trabalho para análise e interpretação de imagens orbitais de alta resolução do sensor Quick Bird, proporcionou os meios para a realização do mapeamento das classes e uso e ocupação do solo na Bacia hidrográfica do Córrego Pararangaba, em nível compatível com os objetivos da pesquisa. Permite inclusive o detalhamento das diferentes classes de adensamento urbano os quais poderão ser aplicados a estudos mais específicos na área da demografia. Os resultados obtidos possibilitaram a análise quantitativa do crescimento urbano no período analisado, o qual concorreu para o aumento dos eventos de inundação, bem como, seus reflexos nos processos de erosão e assoreamento dos córregos, sobrecarregando o sistema da macrodrenagem na área de estudo.

\section{REFERÊNCIA BIBLIOGRÁFICA}

ANDRADE, J. B.; SILVA, F. B.; GUSMÃO, E. R.; BRITO, D. R. B. DOURADO, G. F. Mudança da cobertura vegetal do município de Buriti - MA nos anos de 2000 e 2007: uma abordagem com o uso de geotecnologias. In: XIV Simpósio Brasileiro de Sensoriamento Remoto, 4., 2009, Natal. Anais... São José dos Campos: 
INPE, 2009. Artigos, 5591p. CD-ROM, On-Line. Disponível em: <http://marte.dpi.inpe.br/col/dpi.inpe.br/ sbsr@80/2009/03.02.18.19/doc/capa.htm>. Acesso em: 04 nov. 2010.

BOLOGNA, S. M. F. A Experiência dos Planos Diretores de São José dos Campos: Instrumentos Eficazes de Planejamento ou Obras de Consulta Acadêmica. 2000. f.236. Dissertação (Mestrado em Planejamento Urbano e Regional) Instituto de Pesquisa e Desenvolvimento, Universidade do Vale do Paraíba, São José dos Campos, 2000. 60p.

CÂMARA, G.; SOUZA, R. C. M.; FREITAS U. M.; GARRIDO, J. SPRING: Integrating remote sensingand GIS by object-oriented data modelling. v.03, n.20, 1996. Disponível em: <http://www.comunidadespring. com.br/index.php?option=com_frontpage\&Itemid=1>. Acesso em: 20 jul. 2009.

CAMPOS, S.; BARBOSA, A. P.; MANZANO, L. M.; JARDIM, J.; CERAGIOLI, N. S.; GONÇALVES, S. P. Espacialização do uso da terra na microbacia do Ribeirão Descalvado, Botucatu (SP) no período de 35 anos. Pesquisa Aplicada \& Agrotecnologia. v.2, n.1, 18.p. 2009. Disponível em: $<$ http://revistas.unicentro. br/index.php/repaa/article/viewFile/424/574>. Acesso em: 13 nov. 2010.

Divisão de Meteorologia Aeronáutica do Centro Tecnológico de Aeronáutica. São José dos Campos, 2003. FARINA, F. C.; AHLERT, S.; DURANTI, R. R.; SILVA, T. P.; FAGUNDES, C. L. Utilização de imagem de alta resolução espacial para o mapeamento do município de Monte Belo do Sul, RS. In: XIII Simpósio Brasileiro de Sensoriamento Remoto, 4., 2007, Florianópolis. Anais... São José dos Campos: INPE, 2007. Artigos, p.515-517. CD-ROM, On-Line. Disponível em: <http://www.ltid.inpe.br/sbsr2005/biblioteca/>. Acesso em: 10 nov. 2010.

FREITAS, R. N.; COSTA, S. M. F. Aplicação de técnicas de geoprocessamento na avaliação dos vazios urbanos existentes na cidade de São José dos Campos, SP, em 2005. In: XII Simpósio Brasileiro de Sensoriamento Remoto, 4., 2005, Goiânia. Anais... São José dos Campos: INPE, 2005. Artigos, 3765p. CD-ROM, On-Line. ISBN85-17-00018-8. Disponível em: <http://marte.dpi.inpe.br/col/ltid.inpe.br/sbsr/2004/11.18.13.33/ doc/3763.pdf>. Acesso em: 20 jul. 2009.

GOYA, Y. Projetos de Transporte: Urbanização e Implicações Sociais. In: Congresso Brasileiro de Cadastro Técnico Multifinalitário da UFSC, 10, 1998, Florianópolis, SC. Anais ... Florianópolis: UFSC, 1998. 01p. CD-ROM.

Jornal O Vale. Cidades. Disponível em: <http://www.digitalflip.com.br/ovale/flip/Edicoes/00172=20-10-2010/07.PDF $>$ Acesso em: 22 dez. 2010.

Jornal Valeparaibano. Disponível em: <http://jornal.valeparaibano.com.br/2003/01/23/sjc/chuva2.html > Acesso em 22 mai. 2010.

LANGENBUCH, J. R. Estruturação da Grande São Paulo. Rio de Janeiro: Fundação IBGE, 1971. p.5-153. MARCONDES, M. J. A. Cidade e Natureza: Proteção dos Mananciais e Exclusão Social. São Paulo: EDUSP, 1999. p.93-139.

OLIVEIRA, V. S. Integração SIG e Modelo de Simulação de áreas Inundáveis: Bacia do Rio Pararangaba. 2003. f.68-95. Tese (Mestrado na área Infra - estrutura de Transportes) Engenharia de Infra-estrutura Aeronáutica, Divisão de Pós Graduação do Instituto Tecnológico de Aeronáutica, São José dos Campos, 2003.

OLIVEIRA, I. M.; Costa, S. M. F. Monitoramento da Expansão Urbana, Utilizando Dados de Sensoriamento Remoto - Estudo de Caso. In: X Simpósio Brasileiro de Sensoriamento Remoto, 4, 2001, Foz do Iguaçu, PR. Anais eletrônicos... São Paulo: INPE, 2001. 6p. Disponível em: <http://marte.dpi.inpe.br/col/dpi.inpe. br/lise/2001/09.20.17.19/doc/1131.1138.224.pdf >. Acesso em: 20 jul. 2009.

PAES, F. C.; PINTO, S. A. F.; DUTRA, L. V. Um Estudo Exploratório para Obtenção de Índices de Qualidade de Vida Urbana (IQV) Utilizando Imagens de Alta Resolução do Satélite IKONOS II. In: XI Simpósio Brasileiro de Sensoriamento Remoto, 4., 2003, Belo Horizonte. 2003, Anais... São José dos Campos: INPE, 2003. Artigos, 1907p. CD-ROM, On-Line. ISBN 85-17-00017-X. Disponível em: <http://www.ltid.inpe.br/ sbsr2005/biblioteca/>. Acesso em: 10 nov. 2010.

PERRELLA, A. C. F.; FERREIRA, M. E. Um Estudo Sobre Inundações em São José dos Campos - SP. In: XII Congresso Brasileiro de Meteorologia, 2002, Foz de Iguaçu, PR, 2002. Anais... cbmet. Disponível em: $<$ http://www.cbmet.com/cbm-files/11-74b0a33de3aa24ef7fbc193de91045b7.pdf > Acesso em: 04 fev. 2010. Prefeitura Municipal de São José dos Campos - Defesa Civil. São José dos Campos, 2009. 
Prefeitura Municipal de São José dos Campos - Secretaria de Planejamento Urbano. Banco de Dados Geográfico Cidade Viva. São José dos Campos, 2007. CD-ROM.

Prefeitura Municipal de São José dos Campos - Secretaria de Planejamento Urbano. Banco de Dados Geográfico Cidade Viva. São José dos Campos, 2008. CD-ROM.

Prefeitura Municipal de São José dos Campos - Secretaria de Planejamento Urbano. Banco de Dados Geográfico Cidade Viva. São José dos Campos, 2010. CD-ROM.

SCOFIELD, G. B.; SANTOS, C. C. FERREIRA, N. J.; JORGE, M. P. P. M. Caracterização do clima da cidade de São José dos Campos. In: XI CONGRESSO BRASILEIRO DE METEOROLOGIA, 10, 2000, Rio de Janeiro, RJ. Anais... CBMET, Disponível em: <http://www.cbmet.com/cbm-files/12-ed445e51e12cbcf0b0bb4eae8b80483e.pdf> Acesso em: 20 jul. 2010.

TUCCI, C. E. M. Inundações e Drenagem Urbana. In: Tucci, C. E. M.; Bertoni, J. C. Inundações Urbanas na América do Sul. Porto Alegre: ABRH, 2003. p. 54-99.

Trabalho enviado em janeiro de 2011 Trabalho aceito em maio de 2011 